\title{
EFFECT OF DIFFERENT CLINICAL APPLICATIONS ON PHYSICO- MECHANICAL PROPERTIES OF COMPOSITE RESINS
}

\author{
EFEITO DE DIFERENTES APLICAÇÕES CLÍNICAS NAS PROPRIEDADES FÍSICO- \\ MECÂNICAS DE RESINAS COMPOSTAS
}

\author{
Burak GÜMÜȘTAȘ ${ }^{1}$; Begüm GÜRAY EFES ${ }^{2}$ \\ 1. Department of Restorative Dentistry, Faculty of Dentistry, Medipol University, Istanbul, Turkey. burakgu@gmail.com; 2. Department \\ of Restorative Dentistry, Faculty of Dentistry, Istanbul University, Istanbul Turkey
}

\begin{abstract}
Although clinicians use fluoride agents to reduce the occurrence of caries, and surface sealing agents to protect composite restorations, the effects of these agents on composite resins have not yet been investigated. The goal of this study was to determine the effect of different surface applications (fluoride or surface sealant) on resin composites with different organic structures (Siloranes, Sonicfill, 3M Z550, Kalore). In this study, 120 discs and 120 bars made of composite resin were stored in water for three months before being thermally aged by cycling between $5^{\circ} \mathrm{C}$ and $55^{\circ} \mathrm{C}$ for 10,000 cycles. The discs were $15 \mathrm{~mm}$ in diameter and $1 \mathrm{~mm}$ thick; the bars were $25 \times 2 \times 2 \mathrm{~mm}$. The surface sealant and fluoride were applied to the specimens, and evaluations were performed after $24 \mathrm{~h}$. Initial and final calculations were performed for flexural strength, microhardness, roughness, gloss, water sorption, and solubility. Silorane composite showed the lowest water sorption levels $(p<0.05)$ for both initial and aged groups. Silorane and SonicFill composite groups showed the lowest solubility $(p<0.05)$. Both before and after aging, the SonicFill group showed the highest values of flexural strength and microhardness. Silorane showed the highest roughness and lowest gloss values. Lower water sorption and solubility rates were seen on materials fabricated from hydrophobic monomers. High water sorption and solubility degrades the mechanical and surface properties. Fluoridation and surface sealant application can alter the surface properties but do not have any effect on the mechanical properties.
\end{abstract} properties.

KEYWORDS: Acidulated phosphate fluoride. Adhesives. Mechanical properties. Silorane resins. Surface

\section{INTRODUCTION}

Aesthetic properties are not the only reason why dental composites are widely used today; their ability to adhere to the tooth surface is also very important. Dental composites absorb fluids because of the nature of the organic matrix; sorption is affected by inadequate polymerization or the effects of oral fluids (WEI et al., 2011). Water sorption (WS), which occurs mainly by diffusion into the organic matrix, can result in degradation. Several factors, such as the types of organic fillers, thermal changes, or elapsed time will change the WS amounts (TOLEDANO et al., 2003). When water molecules diffuse into the composite, it expands the material by a process called "hydroscopic expansion," which triggers the chemical degradation that will result in the release of degradation products or filler particles from the material. The degradation of a composite can affect both the mechanical and surface properties of the material (PETROPOULOU et al., 2015, YAP et al., 2002).

Surface micro-irregularities can occur not only by degradation of the composite after aging, but also by the application of acidulated phosphate fluoride (APF). APF, which is used frequently for caries inhibition, contains acids which etch the enamel and consequently enhance the fluoride uptake (YAP et al., 2002). Hydrogen ions from the phosphoric acid and fluoride ions from sodium fluoride are present in the APF solution, and hydrofluoric acid is therefore generated. However, APF solution is also reported to dissolve dental materials that contain inorganic components; this affects the surface properties of dental materials such as composite resins, glass ionomers, and porcelain (MAIA et al., 2003. KIM et al., 2005).

Surface properties are among the main factors affecting the aesthetic appearance of composite materials. Even after employing appropriate finishing and polishing techniques, the surface can exhibit micro-irregularities that initiate material wear. To overcome this problem, a thin low-viscosity resin, called a "surface sealant," can be applied over polymerized composite restorations. Surface micro-irregularities or structural defects that have been filled with resin by capillary action enhance the surface smoothness, which provides a more uniform, regular surface (TAKEUCHI et al., 2003, CATELAN et al., 2010).

To date, no studies have assessed the effects of thermal aging on the mechanical properties or the surface properties (such as roughness and gloss) of composite resins with surface sealing or APF 
treatments. Consequently, our objectives were: (1) to determine whether the aging procedures would alter the mechanical properties of the composites, and (2) to ensure that there would be no alteration in the mechanical and physical properties of the composites as a result of the different surface treatments or aging in water and thermocycling that were finally selected.

\section{MATERIAL AND METHODS}

Four composite resins (Filtek Silorane, GC Kalore, Kerr SonicFill, and Filtek Z550) were studied (Table 1). The samples were fabricated in a Teflon mold covered with a transparent Mylar strip, and gently pressed with a glass slide to expel excess material; the disc-shaped samples were $15 \mathrm{~mm}$ in diameter and $1 \mathrm{~mm}$ thick, while the bars were $25 \times 2$ $\times 2 \mathrm{~mm}$. The composite resins were lightpolymerized (Optilux; Kerr, USA) through the Mylar strip following the manufacturers' instructions. The distance of the tip from the specimen was maintained to within $1 \mathrm{~mm}$. The output of the polymerizing light was verified with a radiometer (Kerr/Demetron, Orange, USA). After polymerization, each of the four groups with the different resins was further subdivided into three subgroups with ten disks and ten bars in each subgroup. Group 1 was the Control group, which was not subjected to any surface treatment. Group 2 consisted of composites that received surface treatment with APF solution for $1 \mathrm{~min}$. Group 3 consisted of composites which were then covered with dental bonding agent as a surface sealing material (Adper Single Bond Plus, 3M ESPE, St Paul, MN,USA) and light-polymerized. The specimens in the same group were stored together in a cylindrical vial in $20 \mathrm{~mL}$ of distilled water at $37^{\circ} \mathrm{C}$ for $24 \mathrm{~h}$. For all three groups, WS and solubility (SL), flexural strength (FS), roughness, and gloss values were measured after $24 \mathrm{~h}$ and again after water immersion for 90 days followed by 10,000 cycles of thermal cycling between $5^{\circ} \mathrm{C}$ and $55^{\circ} \mathrm{C}$.

Table 1: Resin composites used in this study

\begin{tabular}{|c|c|c|c|}
\hline & Filler Loading & Fillers & Matrix \\
\hline $\mathrm{Z550}$ & $\begin{array}{l}\text { Nanohybrid } \\
\% 82 \mathrm{wt} \\
\% 68 \mathrm{vol}\end{array}$ & Zirconia silica, & $\begin{array}{l}\text { Bis-GMA, } \\
\text { UDMA, } \\
\text { Bis-EMA, } \\
\text { TEGMA } \\
\text { PEGDMA }\end{array}$ \\
\hline Siloran & $\begin{array}{l}\text { Microhybrid } \\
\% 76 \mathrm{wt} \\
\% 55 \mathrm{vol}\end{array}$ & $\begin{array}{l}\text { Quarz (silane layer), } \\
\text { radiopaque yttrium fluoride }\end{array}$ & $\begin{array}{l}\text { Silorane }(3,4- \\
\text { epoxycyclohexylethylcyclopolym } \\
\text { ethylsiloxane, } \\
\text { bis-3,4- } \\
\text { epoxycyclohexylethylphenylmeth } \\
\text { ylsilane) }\end{array}$ \\
\hline Sonicfill & $\begin{array}{l}\text { Nanohybrid } \\
\% 83,5 \mathrm{wt} \\
\% 83 \mathrm{vol}\end{array}$ & Glass, oxide, and Silicon dioxide. & $\begin{array}{l}\text { TMSPMA } \\
\text { EBPADMA, } \\
\text { bisphenol-A-bis-(2-hydroxy-3- } \\
\text { mehacryloxypropyl) ether, } \\
\text { TEGDMA }\end{array}$ \\
\hline GC Kalore & $\begin{array}{l}\text { Nanohybrid } \\
\% 82 \mathrm{wt} \\
\% 69 \mathrm{vol}\end{array}$ & $\begin{array}{l}\text { Prepolymerized filler (with } \\
\text { lanthanoid fluoride), } \\
\text { fluoro-alumino-silicate } \\
\text { glass, strontium/barium } \\
\text { glass, silicon dioxide, } \\
\text { lanthanoid fluoride }\end{array}$ & $\begin{array}{l}\text { DX-511, UDMA (urethane } \\
\text { dimethacrylate) and } \\
\text { dimethacrylate co-monomers }\end{array}$ \\
\hline
\end{tabular}




\section{Water sorption and solubility}

WS and SL tests were performed according to ISO 4049, and the calculations were performed using the equations described below:

$$
\begin{aligned}
& W_{\mathrm{sp}}=\left(m_{2}-m_{3}\right) / V \\
& W_{\mathrm{sl}}=\left(m_{1}-m_{3}\right) / V,
\end{aligned}
$$

where $W_{\mathrm{sp}}$ is water sorption, and $W_{\mathrm{sl}}$ is the solubility, which is calculated by weighing the specimens $\left(m_{1}\right)$ after having placed them in a desiccator containing dehydrated silica gel at $37^{\circ} \mathrm{C}$ for $24 \mathrm{~h} ; m_{2}$ is the mass of the specimen in micrograms, after immersion in water followed by removal of the excess water using absorbent paper; $m_{3}$ is the dehydrated mass in micrograms of the specimen after water storage followed by storage in a desiccator containing dehydrated silica gel at $37^{\circ} \mathrm{C}$ until constant mass was achieved (AX200, Shimatzu Corp., Japan); and $V$ is the specimen volume in $\mathrm{mm}^{3}$. An electronic micrometer was used to measure the diameter and thickness of each specimen.

\section{Flexural strength}

A universal testing machine (AGX, Shimatzu, Japan) was used for calculating the FS of the composites. A gap of $20 \mathrm{~mm}$ was maintained between the supports. A load was applied at a constant crosshead speed of $0.5 \mathrm{~mm} / \mathrm{min}$ until fracture occurred.

$\sigma=3 \mathrm{Fl} / 2 \mathrm{bh}^{2}$

$\mathrm{F}$ maximum load (Newton). 1 distance between supports, millimeters. $\mathrm{b}$ width at the centre of the specimen, millimeters. $h$ height at the centre of the specimen, millimeters. d deflection due to load, millimeters.

\section{Microhardness}

Microhardnesses were calculated using an automatic microhardness indenter (Innovatest, England). The Vickers hardness is defined as the test force divided by the apparent area of the indentation under the applied test force. The test
GÜMÜŞTAŞ, B.; EFES, B. G.

load was increased from 0.4 to $500 \mathrm{mN}$ at a constant rate. The load and the penetration depth of the indenter were continuously measured during the load-unload hysteresis.

\section{Roughness and Gloss Measurement}

Gloss was measured at the baseline and after aging with a glossmeter in gloss units (GU) (Elcometer 407, Leicester England) with a $60^{\circ}$ geometry. The average surface roughness $(\mathrm{Ra})$ was measured three times at the baseline and again after aging; a surface roughness tester (Surtronic 25; Taylor-Hobson, Leicester, England) was employed, with a cutoff value of $0.8 \mathrm{~mm}$, a transverse length of $4.5 \mathrm{~mm}$, and a measuring speed of $0.25 \mathrm{~mm} / \mathrm{s}$.

\section{Statistical analysis}

Data distribution was first analyzed for the normal distribution using the Kolmogorov-Smirnov test with a statistical software program (SPSS version 22.0, SPSS Inc., Chicago, IL, USA). A pvalue of $<0.05$ was considered statistically significant. Two-way ANOVA was subsequently employed to examine the composites used. Data from the restorative material and surface treatment data were analyzed using one-way ANOVA and Tukey's test. The data that were not normally distributed were analyzed using the nonparametric Kruskal-Wallis test and the Mann-Whitney U test.

\section{RESULTS}

The mean WS and SL values for the four restorative materials at the baseline and after each surface treatment are displayed in Figures 1 to 5 . The lowest values for sorption were observed for Filtek Silorane $\left(10.1 \mu \mathrm{g} / \mathrm{mm}^{3}\right)$, whereas Filtek Z550 showed the highest sorption value $\left(29.5 \mu \mathrm{g} / \mathrm{mm}^{3}\right)$. SonicFill had the lowest value of SL $\left(2.7 \mu \mathrm{g} / \mathrm{mm}^{3}\right)$, but there was no statistical difference between it and Filtek Silorane $\left(3.1 \mu \mathrm{g} / \mathrm{mm}^{3}\right)$. 


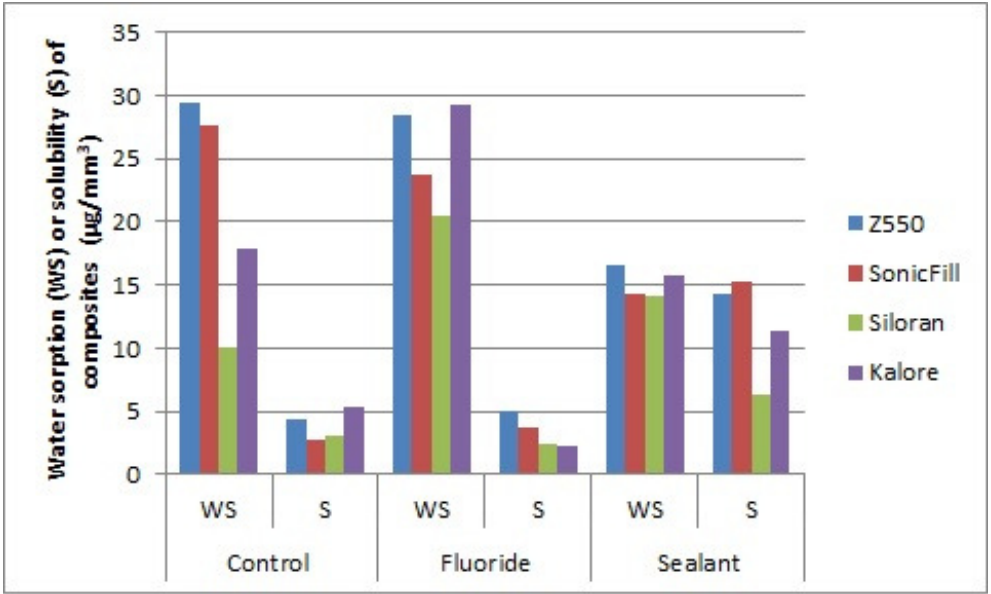

Figure 1. Water sorption (WS) and solubility (S) of composites

FS data are summarized in Figure 2. The statistical analyses indicated that the groups differed significantly $(\mathrm{p}<0.001)$. Specifically, the multiple-comparison test demonstrated that SonicFill possessed the highest FS values; significantly lower values were obtained for Filtek Silorane and Kalore.

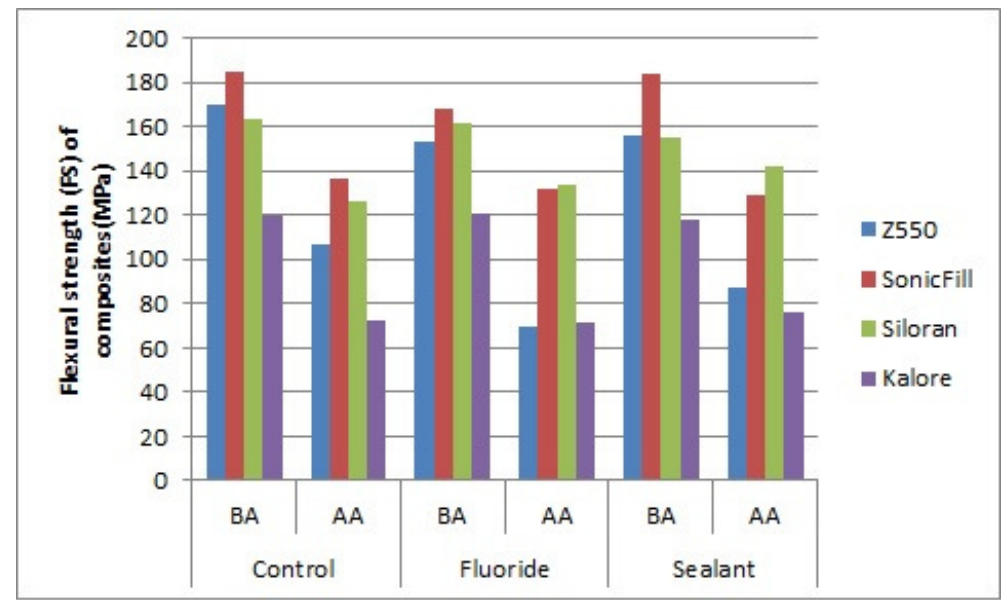

Figure 2. Flexural strength (FS) of composites before aging (BA) and after aging (AA)

Z550 and Sonicfill showed statistically significant reductions in their microhardness values after treatment with fluoride or surface sealant (Figure 3) $(\mathrm{p}<0.05)$. There were statistically significant differences found between the surface roughness (Figure 4) and gloss (Figure 5) of the control, APF-treated, and surface-sealant-treated groups $(\mathrm{p}<0.001)$.

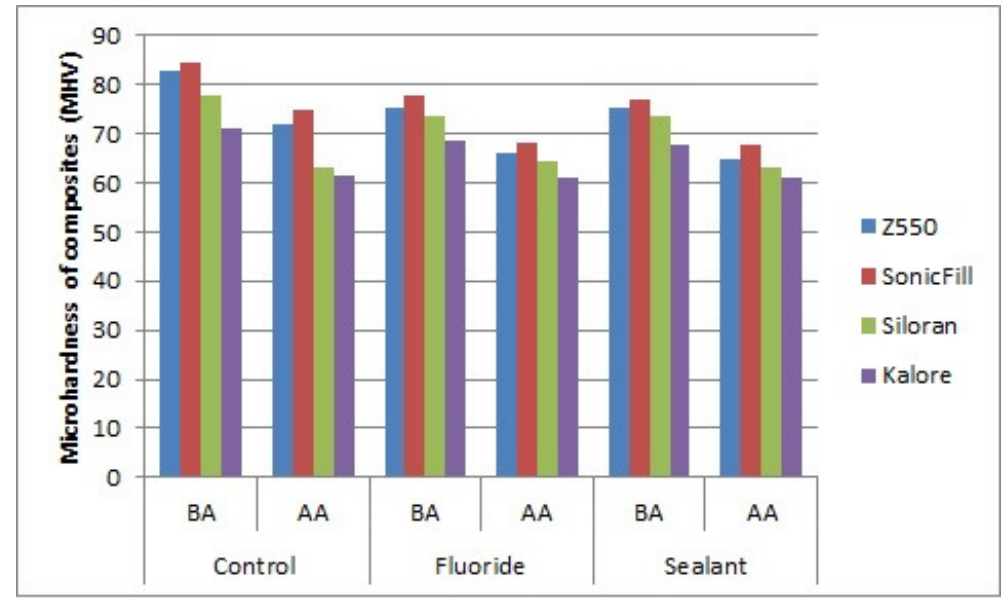

Figure 3. Microhardness of composites before aging (BA) and after aging (AA) 


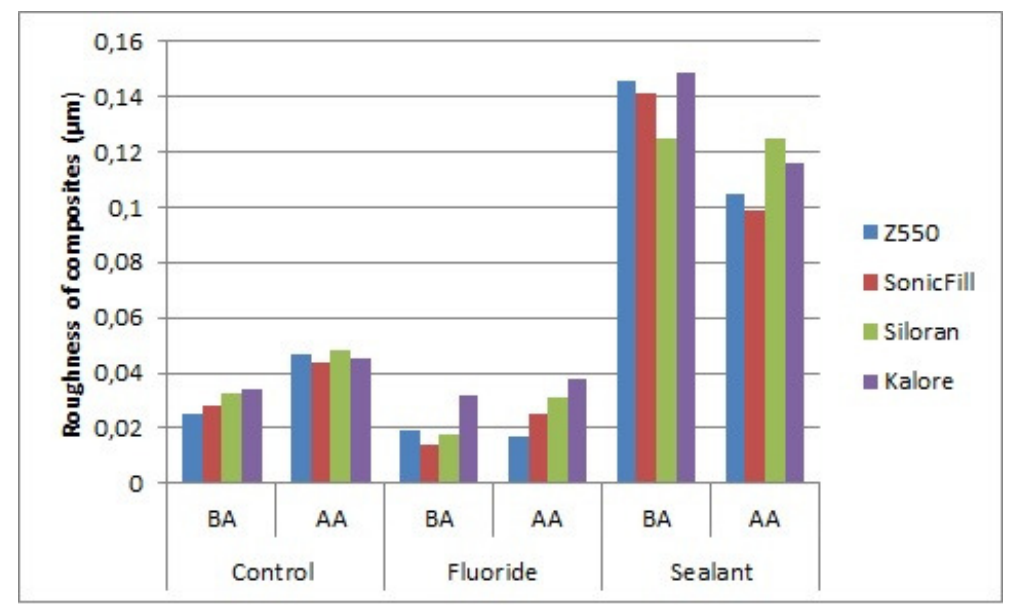

Figure 4. Roughness of composites before aging (BA) and after aging (AA)

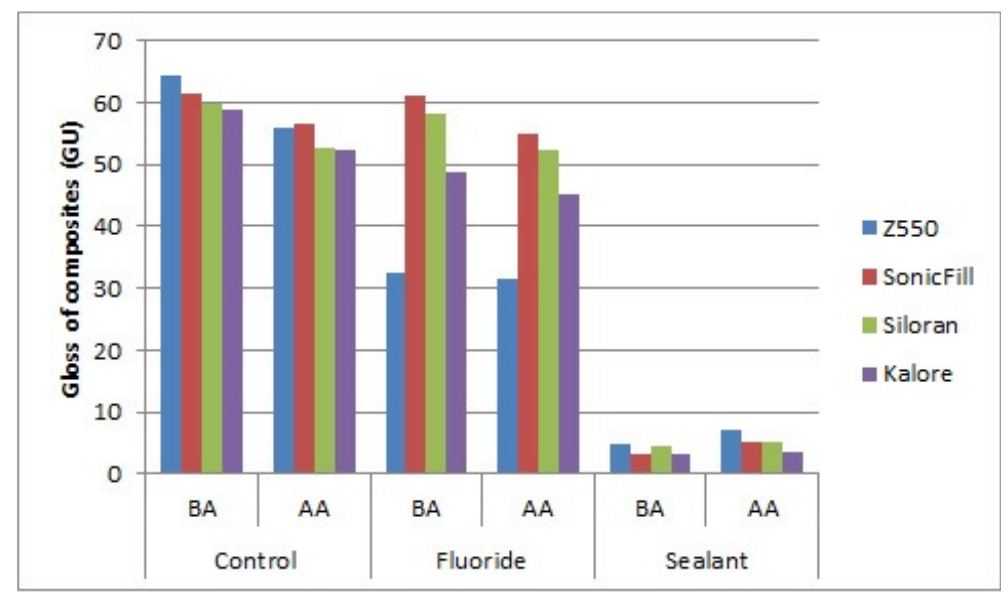

Figure 5. Gloss of composites before aging (BA) and after aging (AA)

\section{DISCUSSION}

These experiments show that aging affected the microhardness, FS, roughness, and gloss of the materials. Application of APF solution or surface sealants on the surface of the composite caused alterations in the microhardness, roughness, and gloss.

Dental composites contain different inorganic fillers (zirconia, quartz, glass) and different organic methacrylate monomers like bisphenol A-glycidyl methacrylate (Bis-GMA), urethane dimethacrylate (UDMA), ethoxylated bisphenol A glycol dimethacrylate (Bis-EMA), triethylene glycol monomethacrylate (TEGMA), or polyethylene glycol dimethacrylate (PEGDMA) together with additives. Manufacturers try to overcome the problem of polymerization shrinkage mainly by increasing the inorganic filler ratio (FONSECA et al., 2017). Another approach that manufacturers employ to overcome polymerization shrinkage is to use "low contraction" monomers like siloranes or DX-511 in the organic matrix of the composites (WEINMANN et al. 2005; SIDERIDOU et al, 2015).

WS of the polymer matrix might influence the hydrolytic stability of dental composites (ÖRTENGREN et al., 2001). Two of the composites (Filtek Z550 and SonicFill) contain mainly BisGMA and Bis-EMA, TEGDMA, and UDMA; organic matrices of this type did not seem to differ from each other in terms of WS levels. The lower WS values of Sonicfill can be explained by the high filler ratio (less organic matrix) in Sonicfill compared with Z550. The hydrophilic nature of BisGMA is the key factor controlling the WS of this material (ITO et al., 2005). The TEGDMA monomer was added to the composites to promote dilatation of the high-viscosity polymer. This monomer used for dilatation, which combines with the hydroxyl groups in the Bis-GMA monomer, can cause WS. WS causes expansion of the restoration, which is destructive to the structure (MARTIN et al., 2003). Two of the composites (Filtek Silorane and GC Kalore) showed less WS and SL than the composites containing Bis-GMA; this can be attributed to the fact that the silorane monomer is 
hydrophobic, whereas the DX-511 monomer is longer and has a higher molecular mass.

FS has been assessed in several previous studies as a clinically relevant property for restorative materials meant to be used in areas that are exposed to force (SHIBASAKI et al., 2017, FINAN et al., 2013, YAMASAKI et al., 2013, GORACCI et al., 2014). The highest FS values measured in our study were for the resin composite SonicFill. The high filler load of SonicFill reportedly renders the composite capable of sustaining the functional stress; moreover, the application of sonic energy lowers its viscosity for improved interfacial adaptation (KAPOOR et al., 2016). Garoushi et al. (2013) noted the absence of a direct relationship between the volumetric content of filler and fracture parameters such as fracture toughness and FS of several commercial composites; they also claimed that other factors besides filler content (such as adhesion between matrix and filler particles, as well as stress transfer between these components) may play a relevant role (GAROUSHI et al., 2013). Kalore exhibited significantly lower FS than the other organic matrix content composites; however, this can be explained by its long monomer structure. The clinical use of SonicFill in high stress-bearing areas is feasible because of its superior mechanical characteristics. Even though SonicFill suffered a significant reduction in FS after aging, it still exhibited excellent performance that can be associated with the bulk-fill composite properties. Moreover, the polymerization shrinkage stress relaxation mechanism could also play a part in reducing the stress levels incurred by hydrolytic expansion.

The filler amount and types of organic matrix of resin composite materials correlate with the hardness of the material and alter the clinical properties, such as resistance to abrasion and polishability. Our study shows that SonicFill has the best values for Vickers hardness, which can be explained by its high inorganic filler content. Filtek Silorane displayed greater hardness than Kalore or $\mathrm{Z550}$, because of its rigid hydrophobic monomer properties.

For all the samples in this study, the measured values of surface roughness ( $\mathrm{Ra}$ ) were less than $0.15 \mu \mathrm{m}$; this is less than the level that would be perceptible by the patient $(0.3 \mu \mathrm{m})$ or even the minimum level needed for biofilm retention $(0.2$ $\mu \mathrm{m})$ (BOLLEN et al., 1997). Therefore, with the use of $1.23 \%$ acidulated fluoride gel and surface sealant, the surface roughness alteration does not exceed the critical level, but remains within clinically acceptable limits.
Surface roughness is not the only parameter that affects aesthetic properties; gloss must also be considered. Gloss can be defined as reflectance of light from the surface. Smooth surfaces reflect more light, and thus, are associated with high gloss (HEINTZE et al., 2006). Inorganic fillers in composite materials play a significant role in determining the optical properties (LIM et al., 2008). Low-roughness composites such as microfilled resin-composites have been shown to possess higher gloss (O'BRIEN et al.,1984). As the surface roughness of a composite resin decreases, its glossiness properties will be increased (ATTAR et al., 2007). Increasing the gloss of a resin composite causes the material to look more aesthetic (LEE et al., 2005).

Composite resins can interact with the fluoride in APF agents through three pathways: the organic matrix, inorganic fillers, or the filler-matrix coupling agents. The hydrogen and fluoride ions in APF gel form hydrofluoric acid which attacks the inorganic filler particles, thereby decreasing the surface hardness of the composite material (YAP et al., 2002). Composites containing barium boroaluminosilicate glass are the most susceptible to attack by APF agents, while microfilled materials are the least sensitive to APF gel (SOENO et al., 2002). The thixotropic and viscosity characteristics of fluoride gels may also affect the surface properties of composites (SOENO et al., 2001).

Although the findings of this laboratory study showed that silorane resins presented good values of sorption and solubility, also a clinical study should be planned to decide effectiveness of silorane and dimethacrylate resins in a complete way.

\section{CONCLUSIONS}

The organic matrix can influence the WS and SL behavior of composite resins. Lower WS and SL rates are seen on materials fabricated from hydrophobic monomers.

Furthermore, high WS and SL degrade the mechanical and surface properties. Fluoridation and surface sealant application can alter the surface properties (hardness, roughness, and glossiness) but do not have any effect on the mechanical properties, such as flexural strength.

\section{ACKNOWLEDGEMENTS}

This work was supported by Scientific Research Projects Coordination Unit of Istanbul University. Project number 20508. 
RESUMO: Embora os clínicos utilizem agentes de flúor para reduzir a ocorrência de cáries e agentes de vedação de superfície para proteger restaurações compostas, os efeitos desses agentes sobre as resinas compostas ainda não foram investigados. O objetivo deste estudo foi determinar o efeito de diferentes aplicações de superfície (fluoreto ou selante de superfície) em resinas compostas com diferentes estruturas orgânicas (Siloranes, Sonicfill, 3M Z550, Kalore). Neste estudo, 120 discos e 120 barras de resina composta foram armazenados em água por três meses antes de serem envelhecidos termicamente por ciclos alternados entre $5{ }^{\circ} \mathrm{C}$ e $55{ }^{\circ} \mathrm{C}$ por 10.000 ciclos. Os discos tinham $15 \mathrm{~mm}$ de diâmetro e $1 \mathrm{~mm}$ de espessura; as barras eram $25 \times 2 \times 2 \mathrm{~mm}$. O selante de superfície e o flúor foram aplicados nos espécimes e as avaliações foram realizadas após 24 horas. Cálculos iniciais e finais foram realizados para resistência à flexão, microdureza, rugosidade, brilho, sorção de água e solubilidade. O compósito de silorano apresentou os menores níveis de sorção de água $(\mathrm{p}<0,05)$ para os grupos inicial e envelhecido. Os grupos compostos Silorane e SonicFill apresentaram a menor solubilidade $(\mathrm{p}<0,05)$. Tanto antes quanto depois do envelhecimento, o grupo SonicFill apresentou os maiores valores de resistência à flexão e microdureza. Silorane apresentou a maior rugosidade e menores valores de brilho. Baixas taxas de sorção e solubilidade da água foram observadas em materiais fabricados a partir de monômeros hidrofóbicos. A alta sorção e solubilidade da água degrada as propriedades mecânicas e de superfície. A fluoretação e a aplicação de selante de superfície podem alterar as propriedades da superfície, mas não afetam as propriedades mecânicas.

PALAVRAS-CHAVE: Fluoreto de fosfato acidulado. Adesivos. Propriedades mecânicas. Resinas de silorano. Propriedades de superfície.

\section{REFERENCES}

ATTAR, N. The effect of finishing and polishing procedures on the surface roughness of composite resin materials. The Journal of Contemporary Dental Practice, v. 8, n. 1, p. 27-35, 2007.

BOLLEN, C.; LAMBRECHTS, P.; QUIRYNEN, M. Comparison of surface roughness of oral hard materials to the threshold surface roughness for bacterial plaque retention: a review of the literature. Dental Materials, $\mathrm{v}$. 13, n. 4, p. 258-69, 1997. https://doi.org/10.1016/S0109-5641(97)80038-3

CATELAN, A.; BRISO, A. L.; SUNDFELD, R. H.; DOS SANTOS, P. H. Effect of artificial aging on the roughness and microhardness of sealed composites. Journal of Esthetic and Restorative Dentistry, v. 22, n. 5, p. 324-30, 2010. https://doi.org/10.1111/j.1708-8240.2010.00360.x

FINAN, L.; PALIN, W. M.; MOSKWA, N.; MCGINLEY, E.L.; FLEMING, G.J.P. The influence of irradiation potential on the degree of conversion and mechanical properties of two bulk-fill flowable RBC base materials. Dental Materials, v. 32, n. 3, p. 29:906-12. 2013

FONSECA, A. S. Q.; MOREIRA, A. D. L; DE ALBUQUERQUE, P. P. A; DE MENEZES, L. R.; PFEIFER, C. S.; SCHNEIDER, L. F. J. Effect of monomer type on the C-C degree of conversion, water sorption and solubility, and color stability of model dental composites. Dental Materials, v. 33, n. 4, p. 394-401, 2017. https://doi.org/10.1016/j.dental.2017.01.010

GAROUSHI, S.; SÄILYNOIA, E.; VALLITTU, P. K.; LASSILA, L. Physical properties and depth of cure of a new short fiber reinforced composite. Dental Materials, v. 29, n. 8, p. 835-41, 2013.

https://doi.org/10.1016/j.dental.2013.04.016

GORACCI, C., CADENARO, M.; FONTANIVE, L.; GIANGROSSO, G.; JULOSKI, J.; VICHI, A.; FERRARI, M. Polymerization efficiency and flexural strength of low-stress restorative composites. Dental Materials, v. 30, n. 6, p. 688-94, 2014. https://doi.org/10.1016/j.dental.2014.03.006

HEINTZE, S.D.; FORJANIC, M.; ROUSSON, V. Surface roughness and gloss of dental materials as a function of force and polishing time in vitro. Dental Materials, v. 22, n. 2, p. 146-65, 2006.

https://doi.org/10.1016/j.dental.2005.04.013 
ITO, S.; HASHIMOTO, M.; WADGAONKAR, B.; SVIZERO, N.; CARVALHO, R. M.; YIU, C.; RUEGGEBERGG, F. A.; FOULGER, S.; SAITO, T.; NISHITANI, Y.; YOSHIYAMAI, M.; TAY, F. R.; PASHLEY, D. H. Effects of resin hydrophilicity on water sorption and changes in modulus of elasticity. Biomaterials, v. 26, n. 33, p. 6449-59, 2005. https://doi.org/10.1016/j.biomaterials.2005.04.052

KAPOOR, N.; BAHUGUNA, N.; ANAND, S. Influence of composite insertion technique on gap formation. Journal of Conservative Dentistry, v. 19, n. 1, p. 77-81, 2016. https://doi.org/10.4103/0972-0707.173205

KIM, Y. J.; JANG, K. T.; GARCIA-GODOY, F. Effect of acidulated phosphate fluoride (APF) gel on the adherence of cariogenic bacteria to resin composites. American Journal of Dentistry, v. 18, n. 18, p. 91-4, 2005.

LEE, Y. K.; LU, H., OGURI, M.; POWERS, J. M. Changes in gloss after simulated generalized wear of composite resins. Journal of Prosthetic Dentistry, v. 94, n. 4, p. 370-6, 2005.

https://doi.org/10.1016/j.prosdent.2005.08.006

LIM, Y. K.; LEE, Y. K.; LIM, B. S.; RHEE, S. H.; YANG, H. C. Influence of filler distribution on the color parameters of experimental resin composites. Dental Materials, v. 24, n. 1, p. 67-73, 2008.

https://doi.org/10.1016/j.dental.2007.02.007

MAIA, L. C.; DE SOUZA, I. P. R.; CURY, J. A. Effect of a combination of fluoride dentifrice and varnish on enamel surface rehardening and fluoride uptake in vitro. European Journal of Oral Sciences, v. 111, n. 13, p. 68-72, 2003. https://doi.org/10.1034/j.1600-0722.2003.00007.x

MARTIN, N.; JEDYNAKIEWICZ, N.M.; FISHER, A.C. Hygroscopic expansion and solubility of composite restoratives. Dental Materials, v. 19, n. 2, p. 77-86, 2003. https://doi.org/10.1016/S0109-5641(02)00015-5

O'BRIEN, W. J.; JOHNSTON, W. M.; FANIAN, F.; LAMBERT, S. The surface roughness and gloss of composites. Journal of Dental Research, v. 63, n. 5, p. 685-8, 1984.

https://doi.org/10.1177/00220345840630051601

ÖRTENGREN, U.; WELLENDORF, H.; KARLSSON, S.; RUYTER, IE. Water sorption and solubility of dental composites and identification of monomers released in an aqueous environment. Journal of Oral Rehabilitation, v. 28, n. 12, p. 1106-15, 2001. https://doi.org/10.1046/j.1365-2842.2001.00802.x

PETROPOULOU, A.; VROCHARI, A.D.; HELLWIG, E,; STAMPF, S.; POLYDOROU, O. Water sorption and water solubility of self-etching and self-adhesive resin cements. Journal of Prosthetic Dentistry, v. 114, n. 5, p. 674-9, 2015. https://doi.org/10.1016/j.prosdent.2015.06.002

SHIBASAKI, S.; TAKAMIZAWA, T.; NOJIRI, K.; IMAI, A.; TSUJIMOTO, A.; ENDO, H.; SUZUKI, S.; SUDA, S.; BARKMEIER, W. W.; LATTA, M. A.; MIYAZAKI, M. Polymerization Behavior and Mechanical Properties of High-Viscosity Bulk Fill and Low Shrinkage Resin Composites. Operative Dentistry, v. 42, n. 6, p. E177-87, 2017. https://doi.org/10.2341/16-385-L

SIDERIDOU, I. D.; VOUVOUDI, E. C.; ADAMIDOU, E. A. Dynamic mechanical thermal properties of the dental light-cured nanohybrid composite Kalore, GC: Effect of various food/oral simulating liquids. Dental Materials, v. 31, n. 2, p. 154-61, 2015. https://doi.org/10.1016/j.dental.2014.11.008

SOENO, K.; MATSUMURA, H.; ATSUTA, M.; KAWASAKI, K. Effect of acidulated phosphate fluoride solution on veneering particulate filler composite. The International Journal of Prosthodontics, v. 14, n. 2, p. 127-32, 2001.

SOENO, K.; MATSUMURA, H.; ATSUTA, M.; KAWASAKI, K. Influence of acidulated phosphate fluoride agent and effectiveness of subsequent polishing on composite material surfaces. Operative Dentistry, v. 27, n. 3, p. 305-10, 2002. 
TAKEUCHI, C. Y.; FLORES, V. O.; DIBB, R. P.; PANZERI, H.; LARA, E. H.; DINELLI, W. Assessing the surface roughness of a posterior resin composite: effect of surface sealing. Operative Dentistry, v. 28, n. 3, p. 281-6, 2003.

TOLEDANO, M.; OSORIO, R.; OSORIO, E.; FUENTES, V.; PRATI, C.; GARCIA-GODOY. F. Sorption and solubility of resin-based restorative dental materials. Journal of Dentistry, v. 31, n. 3, p. 43-50, 2003. https://doi.org/10.1016/S0300-5712(02)00083-0

WEI, Y. J.; SILIKAS, N.; ZHANG, Z. T.; WATTS, D. C. Hygroscopic dimensional changes of self-adhering and new resin-matrix composites during water sorption/desorption cycles. Dental Materials, v. 27, n. 3, p. 259-66, 2011. https://doi.org/10.1016/j.dental.2010.10.015

WEINMANN, W.; THALACKER, C.; GUGGENBERGER, R. Siloranes in dental composites. Dental Materials, v. 21, n. 1, p. 68-74, 2005. https://doi.org/10.1016/j.dental.2004.10.007

YAMASAKI, L. C.; MORAES, A. G. D. V.; BARROS, M.; LEWIS, S.; FRANCCI, C.; STANSBURY, J. W.; PFEIFER, C. S. Polymerization development of "low-shrink" resin composites: Reaction kinetics, polymerization stress and quality of network. Dental Materials, v. 29, n. 8, p. 169-79, 2013. https://doi.org/10.1016/j.dental.2013.04.021

YAP, A.U.; MOK, B.Y. Effects of professionally applied topical fluorides on surface hardness of compositebased restoratives. Operative Dentistry, v. 27, n. 6, p. 576-81, 2002.

YAP, A. U. J.; WEE, K. E. C. Effects of cyclic temperature changes on water sorption and solubility of composite restoratives. Operative Dentistry, v. 27, n. 2, p. 147-53, 2002. 